\title{
Nutrient and salinity concentrations effects on quality and storability of cherry tomato fruits grown by hydroponic system
}

\author{
Mohammad Zahirul Islam ${ }^{1,2}$, Mahmuda Akter Mele ${ }^{1}$, Ki-Young Choi ${ }^{3}$, Ho-Min Kang ${ }^{1,2 \star}$
}

1.Kangwon National University - Division of Horticulture and Systems Engineering - Program of Horticulture - Chuncheon, Gangwon-do, Republic of Korea.

2.Kangwon National University - Agriculture and Life Science Research Institute - Chuncheon, Gangwon-do, Republic of Korea

3. Kangwon National University - Department of Controlled Agriculture - Chuncheon, Gangwon-do, Republic of Korea

\begin{abstract}
This study was conducted to investigate the effects of nutrient and salinity concentrations on the quality of deepflow technique hydroponic system cultivated cherry tomatoes (Lycopersicon esculentum Mill 'Unicorn'). The conditions were: (1) control (NS-1 $\times$ nutrient Solution, Electrical Conductivity - EC: $2.5 \mathrm{mS} \cdot \mathrm{cm}^{-1}$ ); (2) $2 \times \mathrm{NS}\left(2 \times \mathrm{NS}\right.$-Double NS, EC: $\left.5 \mathrm{mS} \cdot \mathrm{cm}^{-1}\right)$; (3) NS $+4.23 \mathrm{mM} \mathrm{NaCl}$ ( $\mathrm{NaCl}$-Sodium Chloride, EC: $5 \mathrm{mS} \cdot \mathrm{cm}^{-1}$ ); and (4) NS + $13.70 \mathrm{mM} \mathrm{Sea}$ Water - SW (EC: $\left.7.5 \mathrm{mS} \cdot \mathrm{cm}^{-1}\right)$. NS + $13.70 \mathrm{mM} \mathrm{SW}$ treatment showed the lowest fresh weight loss. Visual quality as well as shelf life was the longest in NS ( $1 \times$ nutrient solution) treated tomato fruits. The longest
\end{abstract}

shelf life at $5{ }^{\circ} \mathrm{C}, 11^{\circ} \mathrm{C}$, and $24^{\circ} \mathrm{C}$ were 21,16 , and 8 days, respectively, in NS $(1 \times$ nutrient solution) treated tomato fruits. The highest firmness was recorded in NS $(1 \times$ nutrient solution) treated tomato fruits, which was retained after storage. Moreover, NS $+13.70 \mathrm{mMSW}$ treatment increased the cherry tomato fruit's quality, especially soluble solids and sugar contents. These results indicate that salinity concentration has effect the soluble solids and sugar of cherry tomato fruits. In addition, nutrient concentration influenced the shelf life and firmness of cherry tomato fruits.

Key words: firmness, lycopene, soluble solids, sugar, titratable acidity. 


\section{INTRODUCTION}

Currently, salinity treatment of tomato cultivation is taking place in Korea and Japan for enhancing soluble solids. Salinity influenced size and number of marketable fruits, but increased fruit quality by increasing total soluble solids (TSS) and sugar content (Del Amor et al. 2001). TSS is a vital quality criterion for tomato paste processing, serves and price setting for producer (Cuartero and FernándezMuñoz 1998). Increasing salinity improved various aspects of tomato fruit quality, such as proportion of extra fruits (visual quality), soluble solids, and titratable acidity, but decreased fruit size (Magán et al. 2008). TSS was higher in the plants subjected to the salinity treatments (Borghesi et al. 2011). Regardless of the salinization time treatments, tomato fruits of salt-treated plants showed significant upturns in concentration of sugars, total soluble solids and total acid content, since fruit $\mathrm{pH}$ decreased (Del Amor et al. 2001). Hydroponically produced tomatoes with sodium chloride enriched nutrient solution had higher consumer preference, expanded sweetness and flavor, but also produced a harder tomato fruit (Petersen et al. 1998). Yield reduction occurred in the flowering and fruiting stages of salinity-treated tomato fruits, due to reduction of fruit number in lieu of fruits size, but salinity increased fruit quality that depends on developmental stage and application time (Zhang et al. 2017).

The high-quality tomato, which has higher soluble solids, should be needed in the high-end market. Saline cultural condition helps unification some fruit quality of many crops. We used three distribution temperatures $\left(5^{\circ} \mathrm{C}, 11^{\circ} \mathrm{C}\right.$, and $\left.24^{\circ} \mathrm{C}\right)$. Typically during cold supply chains used to export produce to Hong Kong and Japan by ship, $5{ }^{\circ} \mathrm{C}$ and $11^{\circ} \mathrm{C}$ is considered the standard temperature, for local distribution of produce, $24^{\circ} \mathrm{C}$ is ideal. This study was conducted to demonstrate the performance of nutrient and salinity concentrations on quality of deep-flow cultivated cherry tomato 'Unicorn' in different storage temperatures $\left(5^{\circ} \mathrm{C}, 11^{\circ} \mathrm{C}\right.$, and $\left.24^{\circ} \mathrm{C}\right)$.

\section{MATERIAL AND METHODS}

Cherry tomatoes (Lycopersicon esculentum Mill. cv. 'Unicorn') were grown with a deep-flow technique (DFT) hydroponic system in a greenhouse during the winter in Gangwon province. Nutrient solution was supplied based on the Japanese Horticultural Experiment Station, which was adjusted to $2.5 \mathrm{dS} \cdot \mathrm{m}^{-1} \mathrm{EC}$ and $5.8-6.2 \mathrm{pH}$ (Sato et al. 2006). The treatments were: (1) control (NS-1 $\times$ Nutrient Solution, Electrical Conductivity - EC: $\left.2.5 \mathrm{mS} \cdot \mathrm{cm}^{-1}\right)$; (2) $2 \times \mathrm{NS}(2 \times \mathrm{NS}$-Double NS, EC: $\left.5 \mathrm{mS} \cdot \mathrm{cm}^{-1}\right)$; (3) NS $+4.23 \mathrm{mM} \mathrm{NaCl}(\mathrm{NaCl}$-Sodium Chloride, EC: $5 \mathrm{mS} \cdot \mathrm{cm}^{-1}$ ); and (4) NS + $13.70 \mathrm{mM}$ Sea Water - SW (EC: $7.5 \mathrm{mS} \cdot \mathrm{cm}^{-1}$ ). For all treatments, the nutrients were supplied in DFT system that included PVC (polyvinyl chloride) trays, which were $4 \mathrm{~m}$ long, $0.15 \mathrm{~m}$ wide and $0.20 \mathrm{~m}$ deep and regulated by an electric pump set at a rate of $60 \mathrm{~L} \cdot \mathrm{min}^{-1}$. Fruits were treated from third to seventh trusses in tomato plants. Light red maturity stage of tomatoes was harvested to measure harvest time $\left(20^{\circ} \mathrm{C}\right)$ quality and the rest of them were stored in commercial size carton box $(34 \mathrm{~cm} \times 24 \mathrm{~cm} \times 13 \mathrm{~cm})$ at $5{ }^{\circ} \mathrm{C}, 11^{\circ} \mathrm{C}$, and $24^{\circ} \mathrm{C}$ temperatures with $85 \%$ relative humidity (Islam et al. 2013) to measure the quality of cherry tomato.

Minerals were quantified according to Simsek and Aykut (2007) and Islam et al. (2016) by using inductively coupled plasma-atomic emission spectroscopy (Integra XL Dual, GBC, and Melbourne, Victoria) following acidic digestion.

The respiration and ethylene production were measured by a PBI Dansensor (Check Mate 9900, Denmark) and a GC-2010 Shimadzu (Shimadzu Corporation, Japan), respectively. A GC-2010 Shimadzu was equipped with a wax column BP $20(30 \mathrm{~m} \times 0.25 \mathrm{~mm} \times 0.25 \mu \mathrm{m}$, SGE Analytical Science, Australia), and a flame ionization detector. Detector and injector were set at $127{ }^{\circ} \mathrm{C}$, the ovens were set at $50{ }^{\circ} \mathrm{C}$, and $0.67 \mathrm{~mL} . \mathrm{s}^{-1}$ was the carrier gas $\left(\mathrm{N}_{2}\right)$ flow rate (Islam et al. 2016). Gas samples were removed after three hours at the harvest time $\left(20^{\circ} \mathrm{C}\right)$ and six hours on the final storage day $\left(24^{\circ} \mathrm{C}, 11^{\circ} \mathrm{C}\right.$ and $\left.5^{\circ} \mathrm{C}\right)$ from a closed $125 \mathrm{~mL}$ jar containing two cherry tomatoes.

During the storage period, tomatoes' fresh weight loss was measured by subtracting sample weights from their earlier recorded weights; results are mentioned as percentage of weight loss (Mele et al. 2017). Tomatoes' visible quality was subjectively analyzed by quality determinants (freshness, mold growth, decay, shriveling, smoothness, shininess, and similarity). The observed visual quality scale was scored from 1 to 5 ( 5 = excellent; $4=$ very good; 3 = marketable, good; 2 = bad; and 
$1=$ waste $)$ and five panel members assessed the visual quality of the tomatoes during storage (Islam et al. 2016). Penetrometer (DFT-01, TR snc, Italy) was used to measure fruit firmness (N). A Chroma Meter CR 400 Model (Konica Minolta Sensing, Inc., Japan) was used to measure the tomatoes' skin color. Tomatoes $\mathrm{a}^{*}$ and $\mathrm{b}^{*}$ value indicate the degree of redness and yellowness, respectively, in Minolta Chroma Meter (Mele et al. 2017). Redness of tomatoes were noted as $\mathrm{a}^{*} / \mathrm{b}^{*}$ values. Lycopene content was measured by UV-Spectrophotometer (Shimadzu Corporation, Tokyo, Japan; Fish et al. 2002). Soluble solids were assessed by Refractometer (Atago U.S.A. Inc., U.S.A.); results are mentioned in ${ }^{\circ}$ Brix. Titratable acidity was analyzed by DL 22 Food Analyzer (Metter Toledo Ltd., Korea); results are mentioned as percentage of citric acid. Sugars analysis was conducted by a Waters HPLC (Waters Associates, Milford, MA, USA) and the column was $\mathrm{C}_{18}(4.6 \mathrm{~cm} \times 250 \mathrm{~mm}, 5 \mu \mathrm{m}$, Agilent, USA) at $265 \mathrm{~nm}$. The mobile phase flow rates $0.50 \mathrm{~mL} \cdot \mathrm{min}^{-1}$ with $50 \mathrm{mg} \cdot \mathrm{L}^{-1} \mathrm{Ca}$-EDTA (Calcium di-sodium ethylene diamine tetra-acetate) in HPLC grade water solution (Radi et al. 2003).

SPSS V. 16 (SPSS Inc., Chicago, USA) was used to perform the statistical analysis of data. Differences between conditions were analyzed by a DMRT following a one-way ANOVA.

\section{RESULT AND DISCUSSIONS}

Salinity-treated tomato fruits showed higher sodium $(\mathrm{Na})$ content compared with NS $(1 \times$ nutrient solution $)$ and, as a result, those treated tomato fruits were smaller. This finding in supported by Mitchell et al. (1991), who demonstrated that decreased fruit growth due to salinity could be caused by lower mineral uptake during the fruit's development. Ca appears to have a major role in tomato fruit firmness (Islam et al. 2016). Our results showed that NS ( $1 \times$ nutrient solution) treated tomato fruits highly accumulated $\mathrm{Ca}^{2+}$ content (Table 1). High EC had adverse effect on crop growth and yields (Fallovo et al. 2009) and less $\mathrm{Ca}^{2+}$ accumulates in high EC sweet pepper fruit (Tadesse et al. 1999b). As a result, total $\mathrm{Ca}^{2+}$ content remained low in salinity and double-strength nutrient-solution-treated tomato fruits. The diminished uptake of $\mathrm{Ca}^{2+}$ content likely occurred due to $\mathrm{Ca}^{2+}$ and $\mathrm{K}^{+}$uptake competition by root (Kirkby 1979) and osmotic adjustments that affect water uptake by root (Tadesse et al. 1999b). $\mathrm{Na}^{+}$reduces $\mathrm{Ca}^{2+}$ transport and mobility in the plant, which influences the quality in vegetative and reproductive organs, and salinity directly affects nutrient uptake like $\mathrm{Na}^{+}$ reducing $\mathrm{K}^{+}$uptake and $\mathrm{Cl}^{-}$reducing $\mathrm{NO}_{3-}$ uptake (Grattan and Grieve 1998).

Tomatoes treated with NS $+13.70 \mathrm{mM}$ SW had a higher respiration and ethylene production than the control at harvest time $\left(20^{\circ} \mathrm{C}\right.$; i.e., the light red stage). Tomato fruits grown in saline conditions had higher respiration and ethylene production than those in the control condition (Hobson 1988). Moreover, high EC condition increased the respiration in sweet pepper due to osmotic adjustment that cannot retain water and turgor (Tadesse et al. 1999a). The NS + $13.70 \mathrm{mM} \mathrm{SW}$ treated tomato fruits affirmed a higher respiration and ethylene production after storage, which can ripen the fruit and raise its quality. Given that the NS + 13.70 mM SW treated tomato fruits are smaller than those in other treatments, it can increase the respiration and ethylene production (Table 2).

The NS $(1 \times$ nutrient solution $)$ treated tomatoes resulted in diminished fresh weight losses due to less moisture loss in the fruit. The fresh weight loss increased as increasing ionic strength due to higher respiration and transpiration.

Table 1. Mineral content of cherry tomato fruits treated by nutrient and salinity concentrations.

\begin{tabular}{|c|c|c|c|c|c|c|c|c|c|}
\hline \multirow{2}{*}{ Treatments } & Cao & $\mathrm{K}_{2} \mathrm{O}$ & MgO & $\mathrm{NaO}$ & $\mathbf{P}_{2} \mathbf{O}_{5}$ & $\mathrm{Fe}$ & Mn & $\mathrm{Cu}$ & $\mathbf{Z n}$ \\
\hline & \multicolumn{5}{|c|}{ (\%) } & \multicolumn{4}{|c|}{ (ppm) } \\
\hline Control $(1$ × NS) & $0.127 a^{z}$ & $2.443 a b$ & $0.133 b$ & $0.130 \mathrm{~b}$ & $0.637 a$ & $0.183 a b$ & $0.030 a$ & $0.033 a$ & $0.067 a$ \\
\hline $2 \times N S$ & $0.097 \mathrm{~b}$ & $2.687 a$ & $0.100 c$ & $0.137 b$ & $0.617 a b$ & $0.183 a b$ & $0.037 a$ & $0.027 a$ & $0.073 a$ \\
\hline $\mathrm{NS}+4.23 \mathrm{mM} \mathrm{NaCl}$ & $0.107 a b$ & $2.580 a$ & $0.147 a b$ & $0.420 a$ & $0.527 a b$ & $0.133 b$ & $0.037 a$ & $0.027 a$ & $0.060 a$ \\
\hline $\mathrm{NS}+13.70 \mathrm{mM} \mathrm{SW}$ & $0.087 \mathrm{~b}$ & $2.100 \mathrm{~b}$ & $0.167 a$ & $0.403 a$ & $0.287 \mathrm{~b}$ & $0.190 a$ & $0.023 a$ & $0.033 a$ & $0.060 a$ \\
\hline$P$ values & $\star \star \star$ & $\star \star$ & $\star \star \star$ & $\star \star \star$ & ** & * & NS & NS & NS \\
\hline
\end{tabular}

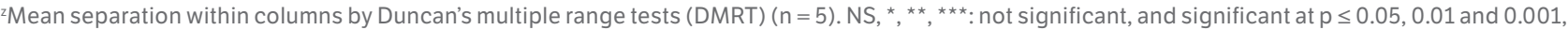
respectively. 
Table 2. Respiration and ethylene production of cherry tomatoes at harvest time $\left(20^{\circ} \mathrm{C}\right)$ and after storage at $5^{\circ} \mathrm{C}, 11^{\circ} \mathrm{C}$, and $24{ }^{\circ} \mathrm{C}$.

\begin{tabular}{|c|c|c|c|c|c|c|c|c|}
\hline \multirow[b]{2}{*}{ Treatments } & \multicolumn{4}{|c|}{ Respiration $\left(\mathrm{CO}_{2} \mathrm{~mL} \cdot \mathrm{kg}^{-1} \cdot \mathrm{hr}^{-1}\right)$} & \multicolumn{4}{|c|}{ Ethylene production rate $\left(\mu \mathrm{L} \cdot \mathbf{k g}^{-1} \cdot \mathbf{h r} \mathbf{r}^{-1}\right)$} \\
\hline & Harvest & $\begin{array}{c}5^{\circ} \mathrm{C} \\
\text { (25 days) }\end{array}$ & $\begin{array}{c}11{ }^{\circ} \mathrm{C} \\
\text { (20 days) }\end{array}$ & $\begin{array}{c}24^{\circ} \mathrm{C} \\
\text { (9 days) }\end{array}$ & Harvest & $\begin{array}{c}5^{\circ} \mathrm{C} \\
\text { (25 days) }\end{array}$ & $\begin{array}{c}11^{\circ} \mathrm{C} \\
\text { (20 days) }\end{array}$ & $\begin{array}{c}24^{\circ} \mathrm{C} \\
\text { (9 days) }\end{array}$ \\
\hline Control $(1 \times \mathrm{NS})$ & $2.28 b^{z}$ & $0.19 b$ & $0.24 b$ & $0.33 b$ & $1.32 \mathrm{~b}$ & $0.25 b$ & $0.39 b$ & $0.48 b$ \\
\hline $2 \times N S$ & $2.30 \mathrm{~b}$ & $0.21 \mathrm{ab}$ & $0.27 a b$ & $0.35 a b$ & $1.35 \mathrm{ab}$ & $0.31 b$ & $0.42 a b$ & $0.49 b$ \\
\hline $\mathrm{NS}+4.23 \mathrm{mM} \mathrm{NaCl}$ & $2.31 \mathrm{ab}$ & $0.23 a b$ & $0.28 \mathrm{ab}$ & $0.36 a b$ & $1.40 \mathrm{ab}$ & $0.37 a b$ & $0.50 \mathrm{ab}$ & $0.63 a b$ \\
\hline $\mathrm{NS}+13.70 \mathrm{mM} \mathrm{SW}$ & $2.38 a$ & $0.27 a$ & $0.33 a$ & $0.40 a$ & $1.49 a$ & $0.52 a$ & $0.58 a$ & $0.76 a$ \\
\hline P values & $\star$ & * & * & * & $\star$ & $\star \star$ & $\star$ & $\star \star$ \\
\hline
\end{tabular}

zMean separation within columns by Duncan's multiple range tests (DMRT) $(n=5) .{ }^{\star},{ }^{\star \star}$ : significant at $p \leq 0.05$ and 0.01 , respectively.

Given that smaller size fruits have large surface areas, they produce more respiration, transpiration (water vapor), and ethylene (Kays and Paull 2004), thus salinity and doublestrength-treated smaller tomato fruits lose fresh weight during storage (Figure 1). The longest shelf life was observed in tomato fruits in NS $(1 \times$ nutrient solution) treatment because of maintaining freshness and marketable visual quality $(\geq 3)$. The shelf life of NS $(1 \times$ nutrient solution), $2 \times \mathrm{NS}, \mathrm{NS}+4.23 \mathrm{mM} \mathrm{NaCl}$, and NS $+13.70 \mathrm{mM} \mathrm{SW}$-treated tomatoes were, accordingly, $21,20,19,18$ days at $5^{\circ} \mathrm{C}, 16,15$, 14,13 days at $11^{\circ} \mathrm{C}$, and $8,7,6,5$ days at $24^{\circ} \mathrm{C}$ (Figure 2). Salinity considerably shortened shelf life by increasing ethylene production in tomato fruits (Mizrahi 1982). The NS $(1 \times$ nutrient solution) treated tomato showed the highest marketable fruit and marketable fruits weight whereas the NS + $13.70 \mathrm{mM} \mathrm{SW}$ treated tomato fruits had shown the lowest due to high salinity concentration (Table 3 ).

In previous research, salinity reduced the strawberry yield due to decreased water content in the fruit (Awang et al. 1993) and high ionic strength in nutrient solution decreased sweet pepper fruit size because of reduced water content that inhibits cell division and cell elongation (Tadesse et al. 1999a). In our experiment, both salinity and doublestrength of the nutrient solution decreased the marketable fruit and marketable fruits weight of tomato.

Color is an important fruit quality parameter, as it impacts seller, buyer, and consumer choices. At the harvest time, color did not show significant difference across the treatment conditions as we selected consistent maturity stage (light red) throughout this experiment; however, color did exhibit significant difference after storage. The highest color development was recorded by the NS $+13.70 \mathrm{mM} \mathrm{SW}$ treated tomato fruits because of the increased respiration and ethylene production, which may help to ripen the fruit quickly (Table 4). This finding is in line with Borghesi et al.
(2011), who suggested that increased salinity enhanced the color development in tomato fruits. In addition, high EC in nutrient solution increased in sweet pepper color because it helps ripening process and maturation (Tadesse et al. 1999b).

The highest firmness was recorded in the NS $(1 \times$ nutrient solution) treated tomato fruits at harvest time due to high Ca content (Table 4) and the highest firmness retained by tomato after storage because of less ethylene production that induce polygalacturonase synthesis activity (Grierson and Tucker 1983). Fruit softening mainly occurs due to middle lamella degradation of cortical parenchyma cells walls with upsurge pectin release (Perkins-Veazie 1995). The NS $(1 \times$ nutrient solution $)$ treated tomato fruits perhaps demonstrate slow degradation and retain the firmness as it contains the maximum $\mathrm{Ca}$ content. Among the salinity treatments, the $\mathrm{NS}+4.23 \mathrm{mM} \mathrm{NaCl}$ treated tomato fruits performed the highest and the NS + $13.70 \mathrm{mM} \mathrm{SW}$ treated tomato fruits obtained the lowest firmness. Higher salinity restricted to deposit of Ca-pectate and Ca-phosphate in the tissue, limiting cell wall development (Minamide and Ho 1993) and increment salinity reduces $\mathrm{Ca}^{2+}$ uptake and xylem transport in tomatoes (Adams and Ho 1993). In the current study, the NS + $13.70 \mathrm{mM} \mathrm{SW}$ treated tomato fruits showed the lowest $\mathrm{Ca}^{2+}$ assimilation because higher $\mathrm{Na}$ content suppressed $\mathrm{Ca}^{2+}$ uptake, as a result, fruits cannot maintain firmness. High ionic strength of nutrient solution showed less firmness due to suppressed to $\mathrm{Ca}^{2+}$ uptake (Tadesse et al. 1999a).

The maximum lycopene content was confirmed in the NS $+13.70 \mathrm{mM}$ SW treated tomato fruits likely due to higher respiration and ethylene production. Salinity-treated tomato fruits increase lycopene content because salinity treatment stimulates respiration and ethylene production, which accelerates ripening (Woo and Kang 2006). 


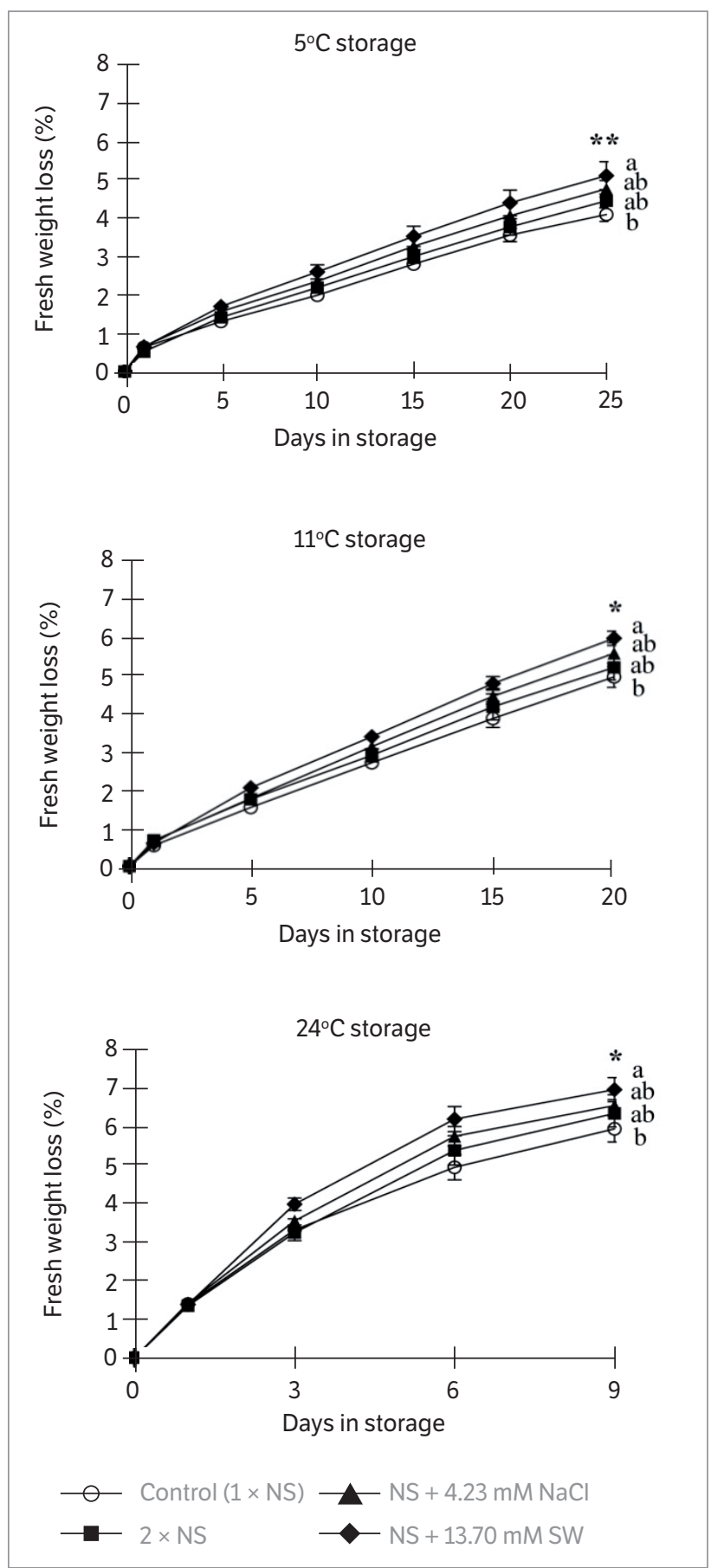

Figure 1. Changes of cherry tomatoes fresh weight loss at $5^{\circ} \mathrm{C}, 11^{\circ} \mathrm{C}$ and $24^{\circ} \mathrm{C}$. Each data point is the mean of ten single fruit replicates \pm standard error. ${ }^{*},{ }^{* *}$ : significant at $\mathrm{p} \leq 0.05$ and 0.01 , respectively, of Duncan's multiple range test (DMRT).

Soluble solids and titratable acidity are important factors for the taste and flavor of tomato fruits. In previous research, increasing salinity improved soluble solids of tomatoes (Magán et al. 2008). Likewise, in this study, higher salinity improved soluble solids (Table 5). Escalation in acidity of

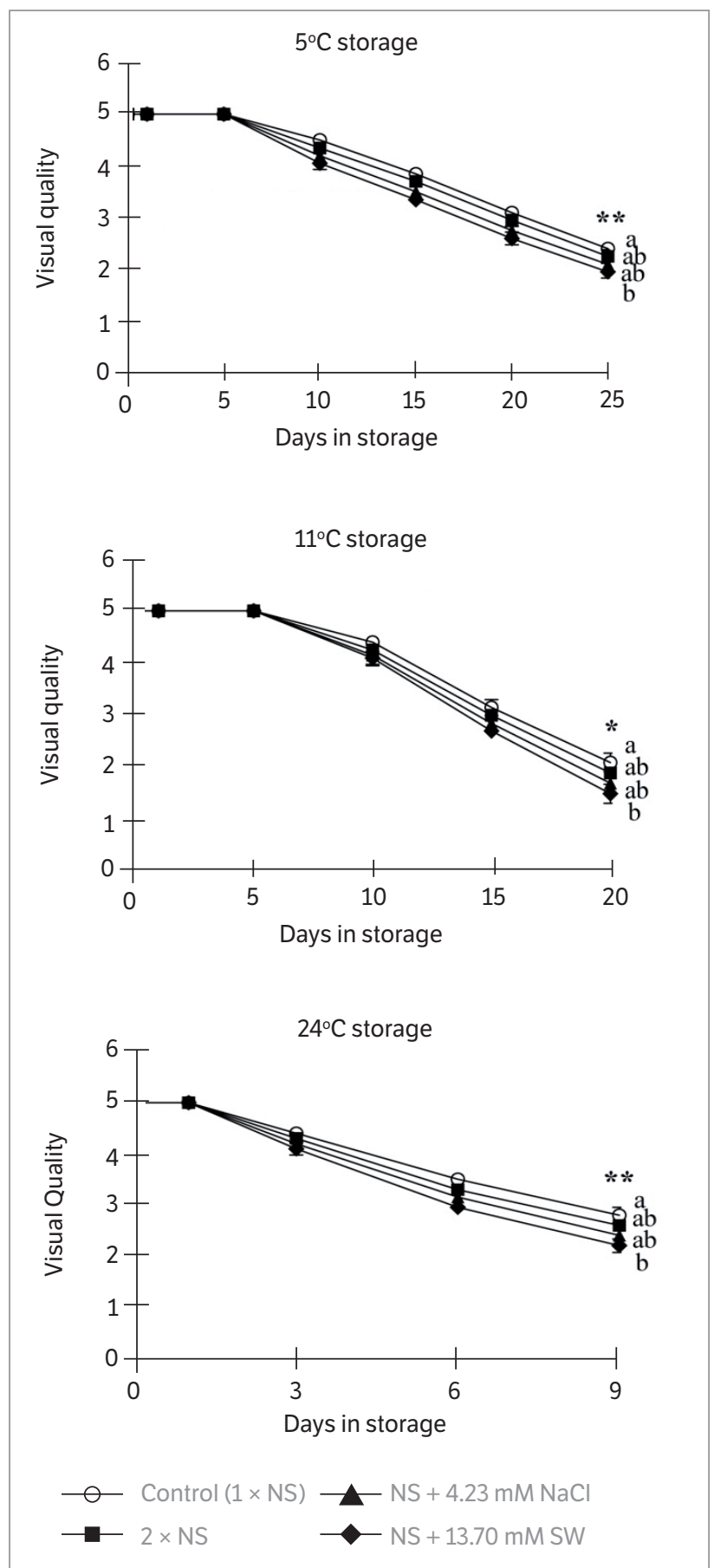

Figure 2. Changes of cherry tomatoes visual quality at $5{ }^{\circ} \mathrm{C}$, $11^{\circ} \mathrm{C}$ and $24^{\circ} \mathrm{C}$. Scale of visual quality: $5=$ excellent; $4=$ very good; $3=$ marketable, good; 2 = bad; and $1=$ waste. Each data point is the mean of ten single fruit replicates \pm standard error. ${ }^{*},{ }^{*}$ : significant at $p \leq 0.05$ and 0.01 , respectively, of Duncan's multiple range test (DMRT).

the fruit could be due to the higher $\mathrm{Na}^{+}$and / or $\mathrm{Cl}^{-}$contents in the fruit given that these are the only ions that increase with salinity (Del Amor et al. 2001). Tomato fruits soluble sugar accumulation increased (Mitchell et al. 1991) due to 
Table 3. Marketable fruits (\%) and marketable fruits weight ( $\mathrm{g} /$ fruit) of cherry tomato treated by nutrient and salinity concentrations.

\begin{tabular}{ccc}
\hline Treatments & Marketable fruits (\%) & Marketable fruits weight (g/fruit) \\
\hline Control $(1 \times \mathrm{NS})$ & $93.20 \mathrm{a}^{2}$ & $13.17 \mathrm{a}$ \\
\hline $2 \times \mathrm{NS}$ & $92.81 \mathrm{a}$ & $11.22 \mathrm{ab}$ \\
\hline $\mathrm{NS}+4.23 \mathrm{mM} \mathrm{NaCl}$ & $92.67 \mathrm{a}$ & $11.94 \mathrm{ab}$ \\
\hline $\mathrm{NS}+13.70 \mathrm{mM} \mathrm{SW}$ & $92.21 \mathrm{a}$ & $9.60 \mathrm{~b}$ \\
\hline $\mathrm{P}$ values & $\mathrm{NS}$ & $*$ \\
\hline
\end{tabular}

"Mean separation within columns by Duncan's multiple range tests (DMRT) $(n=5) . N S$, *: not significant, and significant at $p \leq 0.05$, respectively.

Table 4. Color, firmness, and lycopene of cherry tomatoes at harvest time $\left(20^{\circ} \mathrm{C}\right)$ and after storage at $5^{\circ} \mathrm{C}, 11^{\circ} \mathrm{C}$ and $24^{\circ} \mathrm{C}$.

\begin{tabular}{|c|c|c|c|c|}
\hline Treatments & Harvest & $\begin{array}{c}5^{\circ} \mathrm{C} \\
\text { (25 days) }\end{array}$ & $\begin{array}{c}11^{\circ} \mathrm{C} \\
\text { (20 days) }\end{array}$ & $\begin{array}{c}24^{\circ} \mathrm{C} \\
\text { (9 days) }\end{array}$ \\
\hline & \multicolumn{4}{|c|}{ Color $\left(a^{\star} / b^{\star}\right)$} \\
\hline Control $(1 \times N S)$ & $0.81 a^{z}$ & $0.89 \mathrm{~b}$ & $0.98 b$ & $0.99 b$ \\
\hline $2 \times N S$ & $0.82 a$ & $0.93 a b$ & $1.03 a b$ & $1.04 a b$ \\
\hline $\mathrm{NS}+4.23 \mathrm{mM} \mathrm{NaCl}$ & $0.83 a$ & $0.95 a b$ & $1.02 \mathrm{ab}$ & $1.04 a b$ \\
\hline $\mathrm{NS}+13.70 \mathrm{mM} \mathrm{SW}$ & $0.84 a$ & $0.98 a$ & $1.06 a$ & $1.08 a$ \\
\hline$P$ values & NS & * & ** & ** \\
\hline Treatments & \multicolumn{4}{|c|}{ Firmness (N) } \\
\hline Control $(1$ × NS) & $18.90 a$ & $13.68 a$ & $14.59 a$ & $12.91 a$ \\
\hline $2 \times N S$ & $17.83 a b$ & $12.55 a b$ & $13.18 a b$ & $11.71 a b$ \\
\hline $\mathrm{NS}+4.23 \mathrm{mM} \mathrm{NaCl}$ & $18.32 \mathrm{ab}$ & $13.08 a b$ & $13.78 a b$ & $12.03 a b$ \\
\hline $\mathrm{NS}+13.70 \mathrm{mM} \mathrm{SW}$ & $16.42 b$ & $11.12 b$ & $11.91 b$ & $10.73 b$ \\
\hline$P$ values & * & $\star \star$ & * & * \\
\hline Treatments & \multicolumn{4}{|c|}{ Lycopene (mg/kg FW) } \\
\hline Control $(1 \times N S)$ & $115.07 \mathrm{~b}$ & $163.44 b$ & $168.84 b$ & $171.36 \mathrm{~b}$ \\
\hline $2 \times N S$ & $117.35 b$ & $168.27 a b$ & $174.58 \mathrm{ab}$ & 178.33ab \\
\hline $\mathrm{NS}+4.23 \mathrm{mM} \mathrm{NaCl}$ & $120.48 a b$ & $172.98 \mathrm{ab}$ & 183.92ab & 187.16ab \\
\hline $\mathrm{NS}+13.70 \mathrm{mM} \mathrm{SW}$ & $137.89 a$ & $197.92 a$ & $186.48 a$ & $196.07 a$ \\
\hline$P$ values & ** & * & ** & * \\
\hline
\end{tabular}

"Mean separation within columns by Duncan's multiple range tests (DMRT) $(n=10) . N S,{ }^{*},{ }^{* \star}$ : not significant, and significant at $p \leq 0.05$ and 0.01 , respectively.

Table 5. Soluble solids and titratable acidity of cherry tomatoes at harvest time $\left(20^{\circ} \mathrm{C}\right)$ and after storage at $5^{\circ} \mathrm{C}, 11^{\circ} \mathrm{C}$ and $24^{\circ} \mathrm{C}$.

\begin{tabular}{|c|c|c|c|c|c|c|c|c|}
\hline \multirow[b]{2}{*}{ Treatments } & \multicolumn{4}{|c|}{ Soluble solids ( ${ }^{\circ}$ Brix) } & \multicolumn{4}{|c|}{ Titratable acidity ( $\%$ citric acid) } \\
\hline & Harvest & $\begin{array}{c}5^{\circ} \mathrm{C} \\
\text { (25 days) }\end{array}$ & $\begin{array}{c}11^{\circ} \mathrm{C} \\
\text { (20 days) }\end{array}$ & $\begin{array}{c}24^{\circ} \mathrm{C} \\
\text { (9 days) }\end{array}$ & Harvest & $\begin{array}{c}5^{\circ} \mathrm{C} \\
\text { (25 days) }\end{array}$ & $\begin{array}{c}11^{\circ} \mathrm{C} \\
(20 \text { days })\end{array}$ & $\begin{array}{c}24^{\circ} \mathrm{C} \\
\text { (9 days) }\end{array}$ \\
\hline Control $(1 \times N S)$ & $7.66 b^{2}$ & $7.77 \mathrm{~b}$ & $7.87 \mathrm{~b}$ & $8.24 b$ & $0.65 b$ & $0.54 b$ & $0.46 \mathrm{~b}$ & $0.39 b$ \\
\hline $2 \times N S$ & 7.79ab & 7.87ab & $8.09 a b$ & $8.95 a b$ & $0.70 \mathrm{ab}$ & $0.58 a b$ & $0.50 \mathrm{ab}$ & $0.47 a b$ \\
\hline $\mathrm{NS}+4.23 \mathrm{mM} \mathrm{NaCl}$ & $7.82 a b$ & 7.94ab & $8.14 a b$ & $9.96 a b$ & $0.71 a b$ & $0.61 a b$ & $0.51 a b$ & $0.49 a b$ \\
\hline $\mathrm{NS}+13.70 \mathrm{mM} \mathrm{SW}$ & $8.01 a$ & $8.15 a$ & $9.30 a$ & $9.63 a$ & $0.76 a$ & $0.65 a$ & $0.56 a$ & $0.55 a$ \\
\hline$P$ values & ** & * & ** & $\star \star \star$ & NS & * & * & * \\
\hline
\end{tabular}

${ }^{z}$ Mean separation within columns by Duncan's multiple range tests (DMRT) $(n=10)$. NS, ${ }^{*},{ }^{* \star},{ }^{\star \star \star}$ : not significant, and significant at $p \leq 0.05,0.01$ and 0.001 , respectively.

raised soluble solids and reduced water content in salinity condition (Adams and Ho 1989).

The fructose and glucose were significantly higher in the NS $+13.70 \mathrm{mM}$ SW treated tomato fruits compared with
NS $(1 \times$ nutrient solution $)$ treated tomato at harvest time and after storage (Table 6). Salinity increases sugar and acid content by decreasing the amount of water in tomato fruits, which helps to improve overall taste (Adams and Ho 1989). 
Table 6. Fructose and glucose of cherry tomatoes at harvest time $\left(20^{\circ} \mathrm{C}\right)$ and after storage at $5^{\circ} \mathrm{C}, 11^{\circ} \mathrm{C}$ and $24^{\circ} \mathrm{C}$.

\begin{tabular}{|c|c|c|c|c|}
\hline \multirow[t]{2}{*}{ Treatments } & Harvest & $\begin{array}{c}5^{\circ} \mathrm{C} \\
\text { (25 days) }\end{array}$ & $\begin{array}{c}11^{\circ} \mathrm{C} \\
(20 \text { days })\end{array}$ & $\begin{array}{c}24^{\circ} \mathrm{C} \\
\text { (9 days) }\end{array}$ \\
\hline & \multicolumn{4}{|c|}{ Fructose (g/100g FW) } \\
\hline Control $(1 \times N S)$ & $0.56 b^{z}$ & $1.01 b$ & $1.03 b$ & $1.74 b$ \\
\hline $2 \times N S$ & $0.72 a b$ & $1.24 a b$ & $1.26 a b$ & $2.02 a b$ \\
\hline $\mathrm{NS}+4.23 \mathrm{mM} \mathrm{NaCl}$ & $0.79 a b$ & $1.32 \mathrm{ab}$ & $1.43 a b$ & $2.22 \mathrm{ab}$ \\
\hline $\mathrm{NS}+13.70 \mathrm{mM} \mathrm{SW}$ & $0.88 a$ & $1.59 a$ & $1.68 a$ & $2.57 a$ \\
\hline P values & * & ** & * & * \\
\hline \multicolumn{5}{|c|}{ Glucose (g/ 100g FW) } \\
\hline Control $(1 \times \mathrm{NS})$ & $1.40 \mathrm{~b}$ & $1.75 b$ & $2.38 b$ & $3.98 b$ \\
\hline $2 \times N S$ & 1.69ab & $2.98 \mathrm{ab}$ & $3.44 a b$ & $4.46 a b$ \\
\hline $\mathrm{NS}+4.23 \mathrm{mM} \mathrm{NaCl}$ & $1.81 \mathrm{ab}$ & $3.01 \mathrm{ab}$ & $3.67 a b$ & $4.79 a b$ \\
\hline $\mathrm{NS}+13.70 \mathrm{mM} \mathrm{SW}$ & $2.11 a$ & $3.33 a$ & $5.89 a$ & $5.96 a$ \\
\hline$P$ values & * & $\star \star \star$ & $\star \star \star$ & $\star \star \star$ \\
\hline
\end{tabular}

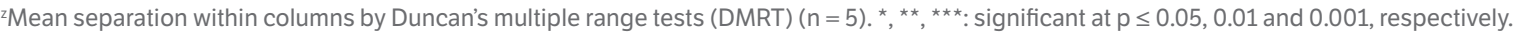

\section{CONCLUSION}

The highest firmness and shelf life was demonstrated in the NS $\left(1 \times\right.$ nutrient solution) tomato fruits because $\mathrm{Ca}^{2+}$ content that can suppress respiration and ethylene production. Moreover, the NS + $13.70 \mathrm{mM} \mathrm{SW}$ treated tomato fruits performed the highest lycopene, soluble solids, fructose and glucose because these treated tomato fruits developed red color quickly as suppressed to uptake $\mathrm{Ca}^{2+}$ content.

\section{ACKNOWLEDGEMENTS}

This research was aided by the Export Promotion Technology Development Program (314027-3),
IPET (Korea Institute of Planning \& Evaluation for Technology), Agriculture, Food and Rural Affairs Ministry, Korea.

\section{ORCID IDs}
M. Z. Islam
D http://orcid.org/0000-0001-7688-463X
M. A. Mele
(D) https://orcid.org/0000-0002-7886-1228
K. Choi
(D) https://orcid.org/0000-0003-4916-0809
H. Kang
(D) https://orcid.org/0000-0003-1703-4699

\section{REFERENCES}

Adams, P. and Ho, L. C. (1989). Effects of constant fluctuating salinity on the yield, quality and calcium status of tomatoes. Journal of Horticultural Science, 64, 725-732. https://doi.org/ 10.1080/14620316.1989.11516015.

Adams, P. and Ho, L. C. (1993). Effects of environment on the uptake and distribution of calcium in tomato and on the incidence of blossom-end rot. In Fragozo M. A. C., Van Beusichem M. L. and Houwers A. (Eds.), Optimization of plant nutrition (p. 583588). Developments in plant and soil sciences, 53. Springer Dordrecht. https://doi.org/10.1007/978-94-017-2496-8_90.

Awang, Y. B., Atherton, G. and Taylor, A. J. (1993). Salinity effects on strawberry plants grown in rockwool. II. Fruit quality. Journal of Horticultural Science, 68, 791-795. https://doi.org/10.1080/ 00221589.1993 .11516414$. 
Borghesi, E., González-Miret, M. L., Escudero-Gilete, M. L., Malorgio, F., Heredia, F. J. and Meléndez-Martínez, A. J. (2011). Effects of salinity stress on carotenoids, anthocyanins, and color of diverse tomato genotypes. Journal of Agricultural and Food Chemistry, 59, 11676 -11682. https://doi.org/10.1021/jf2021623.

Cuartero, J. and Fernández-Muñoz, R. (1998). Tomato and salinity. Scientia Horticulturae, 78, 83-125. https://doi.org/10.1016/ S0304-4238(98)00191-5.

Del Amor, F. M., Martinez, V. and Cerdá, A. (2001). Salt tolerance of tomato plants as affected by stage of plant development. HortScience, 36, 1260-1263.

Fallovo, C., Rouphael, Y., Rea, E., Battistelli, A. and Colla, G. (2009). Nutrient solution concentration and growing season affect yield and quality of Lactuca sativa L. var. acephala in floating raft culture. Journal of the Science of Food and Agriculture, 89, 1682-1689. https://doi.org/10.1002/jsfa.3641.

Fish, W. W., Perkins-Veazie, P. and Collins, J. K. (2002). A quantitative assay for lycopene that utilizes reduced volumes of organic solvents. Journal of Food Composition and Analysis, 15, 309-317. https://doi.org/10.1006/jfca.2002.1069.

Grattan, S. R. and Grieve, C. M. (1998). Salinity - mineral nutrient relations in horticultural crops. Scientia Horticulturae, 78, 127157. https://doi.org/10.1016/S0304-4238(98)00192-7.

Grierson, D. and Tucker, G. A. (1983). Timing of ethylene and polygalacturonase synthesis in relation to the control of tomato fruit ripening. Planta, 157, 174-179. https://doi.org/10.1007/ BF00393652.

Hobson, G. E. (1988). Pre- and post-harvest strategies in the production of high quality tomato fruit. Applied Agricultural Research, 3, 282-287.

Islam, M. Z., Mele, M. A., Baek, J. P. and Kang, H. M. (2016). Cherry tomato qualities affected by foliar spraying with boron and calcium. Horticulture, Environment, and Biotechnology, 57, 46-52. https://doi.org/10.1007/s13580-016-0097-6.

Islam, M. Z., Baek, J. P., Kim, Y. S. and Kang, H. M. (2013). Characteristics of chilling symptoms of cherry tomato compared to beefsteak tomato harvested at different ripening stages. Journal of Pure and Applied Microbiology, 7, 703-709.

Kays, J. S. and Paull, E. R. (2004). Postharvest biology. Athens: Exon Press.
Kirkby, E. A. (1979). Maximizing calcium uptake by plants. Communications in Soil Science and Plant Analysis, 10, 89-113. https://doi.org/10.1080/00103627909366881.

Magán, J. J., Gallardo, M., Thompson, R. B. and Lorenzo, P. (2008). Effects of salinity on fruit yield and quality of tomato grown in soil-less culture in greenhouses in Mediterranean climate conditions. Agricultural Water Management, 95, 10411055. https://doi.org/10.1016/j.agwat.2008.03.011.

Mele, M. A., Islam, M. Z., Baek, J. P. and Kang, H. M. (2017). Quality, storability, and essential oil content of Ligularia fischeri during modified atmosphere packaging storage. Journal of Food Science and Technology, 54, 743-750. https://doi. org/10.1007/s13197-017-2514-y.

Minamide, R. T. and Ho, L. C. (1993). Deposition of calcium compounds in tomato fruit in relation to calcium transport. Journal of Horticultural Science, 68, 755-762. https://doi.org/ 10.1080/00221589.1993.11516409.

Mitchell, J. P., Shennan, C. and Grattan, S. R. (1991). Developmental changes in tomato fruit composition in response to water deficit and salinity. Physiologia Plantarum, 83, 177-185. https://doi.org/10.1111/j.1399-3054.1991.tb01299.x.

Mizrahi, Y. (1982). Effect of salinity on tomato fruit ripening. Plant Physiology, 69, 966-970. https://doi.org/10.1104/pp.69.4.966.

Perkins-Veazie, P. (1995). Growth and ripening of strawberry fruit. In Janick J. (Ed.), Horticultural Reviews, 17 (p. 267-297). Oxford: John Wiley \& Sons, Inc. https://doi.org/10.1002/9780470650585. ch8.

Petersen, K. K., Willumsen, J. and Kaack, K. (1998). Composition and taste of tomato as affected by increased salinity and different salinity sources. The Journal of Horticultural Science and Biotechnology, 73, 205-215. https://doi.org/10.1080/146 20316.1998.11510966.

Radi, M., Mahrouz, M., Jaouad, A. and Amiot, M. J. (2003). Influence of mineral fertilization (NPK) on the quality of apricot fruit (cv. Canino). The effect of the mode of nitrogen supply. Agronomie, 23, 737-745. https://doi.org/10.1051/agro:2003052.

Sato, S., Sakaguchi, S., Furukawa, H. and Ikeda, H. (2006). Effects of $\mathrm{NaCl}$ application to hydroponic nutrient solution on fruit characteristics of tomato (Lycopersicon esculentum Mill.). Scientia Horticulturae, 109, 248-253. https://doi.org/10.1016/j. scienta.2006.05.003. 
Simsek, A. and Aykut, O. (2007). Evaluation of the microelement profile of Turkish hazelnut (Corylus auellana L.) varieties for human nutrition and health. International Journal of Food Sciences and Nutrition, 58, 677-688. https://doi. org/10.1080/09637480701403202.

Tadesse, T., Nichols, M. A. and Fisher, K. J. (1999a). Nutrient conductivity effects on sweet pepper plants grown using a nutrient film technique 1. Yield and fruit quality. New Zealand Journal of Crop and Horticultural Science, 27, 229-237. https:// doi.org/10.1080/01140671.1999.9514101.

Tadesse, T., Nichols, M. A. and Fisher, K. J. (1999b). Nutrient conductivity effects on sweet pepper plants grown using a nutrient film technique 2. Blossom-end rot and fruit mineral status. New Zealand Journal of Crop and Horticultural Science, 27, 239-247. https://doi.org/10.1080/01140671.1999.9514102.

Woo, C. and Kang, W. (2006). Use of East deep sea water for the increase of functional components of ginseng (Panax ginseng C.A. Meyer) and tomato (Lycopersicon esculentum L.). Korean Journal of Plant Resources, 19, 331-335.

Zhang, P., Senge, M. and Dai, Y. (2017). Effects of salinity stress at different growth stages on tomato growth, yield and water-use efficiency. Communications in Soil Science and Plant Analysis, 48, 624-634. https://doi.org/10.1080/001036 24.2016.1269803. 